\title{
O efêmero como confluência entre a filosofia de Jankélévitch e a poética de Laura Vinci
}

JORDANO W. HeRnÁNDEZ

MESTRANDO NO DEPARTAMENTO DE FILOSOFIA DA UFRJ

A compreensão de obra de arte sofreu significativa alteração na contemporaneidade. $\mathrm{O}$ objeto não é o produto acabado, mas parte de um processo. $\mathrm{O}$ espaço torna-se a moldura. O tempo passa a ser o lugar, a prioridade é dada não a um objeto estático, mas àquele em movimento, sujeito a mudanças e à corrupção. A arte controverte os limites previamente impostos.

A obra de arte passa assimilar o movimento, não é mais algo exclusivamente estático. Essa é uma proposta presente na poética de diversos artistas plásticos como em Laura Vinci. A escolha de Vinci, como objeto de reflexão filosófica se faz porque elementos como passagens, transiçôes, mudanças de estado aparecem, em suas obras, como uma marca de seu trabalho. Vinci nos faz pensar sobre os efeitos do tempo, a realidade, a vida e a morte, temas que estão essencialmente vinculados à condição humana. Essa nova concepção artística da temporalidade, que incorpora o fluido e o fugidio, encontra nítida ressonância no pensamento de Vladimir Jankélévitch. O conceito de quase-nada (presque-rien) possui um vínculo estreito com os temas da efemeridade e da impermanência.

Para a efetivação dos objetivos propostos adotou-se os seguintes passos metodológicos: breve explanação do pensamento filosófico de Vladimir Jankélévitch 
e de alguns de seus conceito-chaves, como quase-nada. Por conseguinte, o foco passa a assimilação do efêmero por parte da arte até a proposta de uma estética do efêmero na contemporaneidade, como resultado de uma mudança de paradigma ontológico.

Após esse percurso, analisou-se alguns trabalhos elegidos da artista plástica Laura Vinci, que em suas instalações, trata a problemática do movimento, da transformação e do tempo. Mais que uma ilustração, os trabalhos de Vinci aqui apresentados são os objetos de estudo, caminho de reflexão para compreensão da poética do efêmero.

\section{O pensamento filosófico de Jankélévitch}

Para melhor compreender como o efêmero participa da obra de arte contemporânea, esta reflexão recorreu ao pensamento de Vladimir Jankélévitch filósofo francês de origem russa -, uma vez que essa proposta de efemeridade e fluidez encontra nítida ressonância em sua filosofia. Seu conceito de "quase-nada" (presque-rien) - fundamental em seu pensamento - possui estreito vínculo com o tema do impermanente. Apesar do filósofo não refletir diretamente a temática da arte contemporânea円é possível identificar relevantes implicações estéticas e ontológicas.

Como ponto de partida, se pode afirmar que Jankélévitch não é um substancialista, certo de possuir a verdade sobre o Ser das coisas. Para ele, não se pode e não há possibilidade de responder ao que é o Ser do real, visto que o mundo é efetividade e só se pode dizer que ele "é" (le quid) e constatar que ele existe (le quod): “(...) o ser é o que é" [ Ora, o quod íntimo é a condição constitutiva do homem: ser numa realidade que ele não pode de nenhuma forma se separar, mas sem saber o como e nem o porquê. Qualquer atitude que não assuma tal contradição estaria sendo, na concepção do filósofo, uma arrogância de quem “(...) interpreta como verdades eternas suas próprias presunções e, portanto, perde

${ }^{\text {I }}$ Ao longo de sua tarefa filosófica, o principal foco da pesquisa estética de Jankélévicth é o fenômeno musical, e em raras ocasióes, às artes visuais. O escopo deste artigo é o diálogo de sua filosofia com a arte plástica contemporânea.

${ }^{2}$ JANKÉLÉVITCH, Vladimir. La manière et l'occasion. Paris: Éditions du Seuil, i98o, p. I5. 
seu alvo" 3 Segundo o filósofo francês dizer ser a linguagem, o mundo e a própria existência o fundamento da realidade conduziria a uma "meontologia" que se dirige a entes intermediários. Por esta razão, Jankélévitch fará uso do recurso da via negativa, através de um conceito que diz e nega ao mesmo tempo: Nescioquid, o que Jankélévitch denominará de je-ne-sais-quoi (não-sei-o-quê).

O je-ne-sais-quoi não é propriedade ou modalidade do ser, mas o sujeito mesmo. É importante ressaltar que não é um não-ser, a negação de todo o ser, mas é a constatação do quod. O je-ne-sais-quoi é identificado, em sentido positivo, por Jankélévitch como um quase nada, pois é algo que não é nada, de modo que é um quase-nada (presque-rien), uma presença. Mas o que ele entende por quase nada?

O quase-nada é o elemento invisível, impalpável, ambíguo. "O quase-nada é aquilo que falta quando, ao menos aparentemente, nada falta: é a inexplicável, irritante, irônica insuficiência de uma totalidade completa à qual nada podemos repreender e que nos deixa curiosamente insatisfeitos e perplexos" 4 Essa insatisfação viria justamente quando a totalidade se encontra desprovida de defeitos, em que a falta de evidência de uma lacuna de uma carência sempre indemonstrável é que coloca, no entender de Jankélévitch, o verdadeiro problema metafísico. Para o filósofo, o quase-nada é um conhecimento que sabe e não sabe e, por outro lado, não se conhece seu nome, nem determinar sua natureza. Em virtude dessa indefinição, é identificado como je-ne-sais-quoi, de forma que antes de saber que "é” falta, sabe-se que ele corresponde à falta de um não-sei-quê.

Jankélévitch notará que o ser se desenvolve com o tempo, que é o modo de ser, de se fazer-ser. Pois o tempo não é pura continuação do ser, mas inovação contínua. É intervalo que se resolve infinitamente (“à l’infini”) em instantes virtuais, inumeráveis na massa fluida da continuação. Há uma sucessão de eventos que se torna e acontece e acontece e torna-se. Jankélévitch passará a analisar a ocasião, que não se reduz em um instante, mas um instante que é uma oportunidade de realização, de conhecimento ou de amor. A oportunidade é o momento do tempo em que certo presente se apresenta, em que encontramos a ocorrência no nosso caminho.

${ }^{3}$ LISCIANI-PETRINI, Enrica. In diálogo con Vladimir Jankélévitch. Milan; Paris: Vrin, 2009, p. I9.

${ }^{4}$ JANKÉLÉVITCH, i98ob, p. 74. 
Nossa época é identificada como a sociedade pós-moderna, em transição para uma nova época, cuja configuração e perspectivas não se pode ao certo delinear, tudo está relativizado. Ora, a arte encontra-se inserida nesta visão de mundo contemporânea em que nada mais é eterno, mas fluido e efêmero. Contexto que o pensamento de Vladimir Jankélévitch contribui a entender, através de sua concepção sobre o quase-nada, a questão da efemeridade. Sua filosofia meontológica, inspirada numa tradição filosófica que vem desde Plotino até a Bergson, compreende o real na imanência, no aqui que se dá a efetividade do ser. Entretanto, um ser não estático, e sim fluido, que acolhe a aparência como uma forma de ser.

\section{A poética do efêmero}

De partida, seria interessante conceituar o que se entende por efêmero. $\mathrm{O}$ efêmero, vocábulo de origem grega, tem como significado original "durante um dia” (epi - cerca de, durante + hemeros - dia). Há no étimo a própria conotação de temporalidade. Transmite a ideia do transitório, da brevidade. Entretanto este artigo adota a compreensão de Buci-Glucksmann que entende: "O efêmero não é o tempo, mas sua vibração tornada sensível”. p De acordo com Buci-Glucksmann, o efêmero pode ser entendido, ainda, como uma arte do tempo que consiste em acolher, em ceder ao tempo e aceitar que ele é, mesmo que imprevisível.

Constata-se que sucedeu uma transformação da compreensão ontológica na atualidade. Esta permite, agora, acolher o sensível, o imanente, a realidade com toda a sua ambiguidade, com sua afirmação e negação (não no sentido de oposição entre si). Essa nova forma de se relacionar com o mundo também servirá de paradigma para arte. A arte não estará mais em busca de uma ordem e harmonia do mundo. Seu objetivo passa a ser expressar o que artista sente e como percebe a realidade, o lugar próprio da experiência. Nesse sentido, a arte contemporânea incentiva o espectador a uma interação junto à obra. Algumas obras de arte acontecem num processo temporal. Nos anos 1970 teremos uma ênfase, por parte dos artistas e teóricos da arte, na relação tempo e movimento e a percepção que se tem da obra: "O frágil, o efêmero, o transitório, tornaram-se

5 BUCI-GLUCKSMANN, Christine. Esthétique de l'éphémère. Paris: Éditions Galilée, 2003 , p. 26. 
temas dominantes nas propostas artísticas desta época. $\mathrm{O}$ tempo tornou-se não apenas um tema recorrente, mas também a metodologia que define a própria natureza do trabalho de arte" 6

Uma melhor aceitação do efêmero só foi possível por uma mudança cultural, ontológica. De uma cultura da estabilidade para uma cultura de fluxos, de “(...) movimento fluido, em transições ambíguas e em mudanças imperceptíveis, que realizou o efêmero de imagem-fluida (...)", 7 como descreve Buci-Gluckmann. Essa é realidade da era contemporânea, de uma sociedade fragmentada, fugaz e ambígua.

Neste cenário dar-se-á a condição para uma nova compreensão e tratamento do efêmero pela arte contemporânea. Não se trata mais de algo exclusivamente estático, como era anteriormente. E esse entendimento se faz presente na poética de diversos artistas plásticos como o da brasileira Laura Vinci. Passagens, transições, mudanças de estado aparecem, em suas obras, como características de seu trabalho. A análise de alguns trabalhos de Vinci se justifica para apresentar o que é, deveras, uma obra de arte efêmera e num diálogo com a filosofia de Jankélévitch.

\section{Envolver-se com o tempo: a poética de Laura Vinci}

Este artigo parte da constatação de uma mudança filosófica e artística significativa na cultura ocidental. Mudança essa que se reflete de uma cultura de estabilidade a uma cultura de fluxo, que lida, agora, com a questão do efêmero de modo distinto. A vantagem de aprofundar a obra de um artista é que muito além de uma mera ilustração, o artista, como explica Tassinari, está: "Entregues ao presente, aceita-se e interpreta-se a situação, mas ao mesmo tempo se a critica, tomam-se distância. Não se opta nem pela indiferença nem por falsas promessas" 8 E essa distância permitiria uma melhor compreensão da questão. Tendo em vista esses pressupostos que se apresentou a artista brasileira Laura Vinci como companhia nessa vereda reflexiva sobre a poética do efêmero.

${ }^{6}$ CARVALHO, Victa. "Dispositivo e experiência: relaçôes entre tempo e movimento na arte contemporânea”. In: Revista Poiésis, Niterói, n. I2, pp. 39-50, nov. 2008, p. 4I.

7 BUCI-GLUCKSMANN, op. cit., p. 57.

${ }^{8}$ TASSINARI, Alberto. “Formas do repouso”. In: VINCI. Laura. Laura Vinci. São Paulo: Editora da Universidade de São Paulo, 2003, p. 156. 
Laura Vinci iniciou seus trabalhos com pintura na década de 1980, migrando gradualmente para a escultura e também instalaçôes. Sua poética comunica muito da transformação, em sua obra encontram-se água, areia, vidro, orgânicos, materiais sólidos e fluidos, materiais em diferentes estados, sujeitos às condiçôes ambientais e leis físico-químicas. Há uma preocupação em propor ao espectador a vivência da passagem, da transição, do "(...) envolvimento corporal com o tempo.'?9

A poética do efêmero busca apreender o tempo, materializá-lo, assim como fez o impressionismo ao se dirigir a algo não palpável. Mas, embora a poética do efêmero não se utilize de tonalidades de cores, ela recorre, assim como os impressionistas, a elementos que evocam a ação do tempo: água, elementos orgânicos como frutas e flores. Elementos que suscitam no espectador a percepção da transformação, o escorrer, mudanças perceptíveis. A poética do efêmero sente na materialização da passagem do tempo o seu rastro: o tempo age na imediaticidade do agora, mas não o vemos a olho nu, só no instante dos seres. Como se afirmasse a ideia, um tanto paradoxal, de que de permanente só a efemeridade do tempo.

O movimento é uma marca nas esculturas de Vinci: movimento sutil, que muitas vezes se apresenta sereno e equilibrado, numa rede de relaçóes em que um elemento implica o outro, em que se sente a ocorrência de uma mudança, mas não se sabe ao certo o que está a mudar. "São transformações e trocas sem nostalgia. Movimentos que buscam repetir, copiar a vida. Um esforço para provocar no observador o instante da percepção, conquistar o olhar, o estado de olhar. A ideia de movimento é otimista, são transformações sem perdas" [ـ É uma proposta de olhar distinto em relação à vida. Não mais melancólico saudosista, do que se foi, de algo que se perdeu, mas como a própria artista ressalta, que manifesta um otimismo, uma atitude nova diante da transformação, diante do efêmero.

As esculturas de Laura nos provocam uma atitude de não nos estacionarmos nas primeiras impressões, deve-se ir além delas, refleti-las. Pois à primeira vista quase não se nota o que se passa, é preciso gastar tempo para perceber o que

9 NAVES, Rodrigo. "Mona Lisa no meio do redemoinho". In: O vento e o moinho: ensaios sobre arte contemporânea. São Paulo: Companhia das Letras, 2007, p. 358.

Io VINCI, Laura. Entrevista de Laura Vinci a Hélio Hara. Seção textos. Disponível em https://www.lauravinci.com.br/textos. Acesso em 23 nov. 202I. 
acontece de imperceptível, observar o momento, cada instante. As obras de Vinci com suas transformações serenas nos sugerem que talvez o mundo não seja uma coisa estável e formalizada ou, seguindo as palavras de Nietzsche, que “(...) a efetividade nos mostra uma embevecedora riqueza de tipos, a exuberância de um perdulário jogo de mudança de formas (...)" [II Talvez, deveras, o que se busca até hoje tenha sido ideias de como deveria ser o mundo, o homem. Uma forma para como as coisas deveriam ser. Quiçá Jankélévitch esteja certo de que a essência do ser seja mesmo o tempo, e este seja o que garante a inovação contínua do ser.

A meu ver, porém, o que confere singularidade às obras de Laura é a sucessão, nos sistemas que constrói, de situações mais harmônicas e de relações aversivas (...) Observando a série de seus últimos trabalhos, tem-se a impressão de que se depreende daí um mundo presidido por cisóes e continuidades, fluidez e rupturas.$^{12}$

Para uma melhor compreensão dessas relações de cisão, continuidade e fluidez, propõe-se aprofundar em detalhe algumas obras de Vinci.

\section{Elementos sólidos}

Abordar-se-á duas obras de Vinci que utilizam elementos sólidos: Ampulbeta (1997) com areia e Máquina do mundo (2005) com pó de mármore. A escultura Máquina do mundo(Figura I) consiste em uma máquina dosadora e uma correia transportadora que carrega o pó de mármore de um lado a outro, de acordo com a explicação da própria artista, "do nada para o nada”. Há, de um lado, um monte de pó de mármore sobre a dosadora, que percorre a correia transportadora até ser despejado na direção oposta. Esta obra busca trabalhar com a ideia de transformação no tempo, como se fosse uma espécie de "ampulheta maquínica”, destacando ao espectador a transitoriedade das coisas.

\footnotetext{
II NIETZSCHE, Friedrich Wilhelm. Obras incompletas. São Paulo: Nova Cultura, 1987, p.

${ }^{12}$ NAVES, op. cit., pp. 366-367.
} II4. 


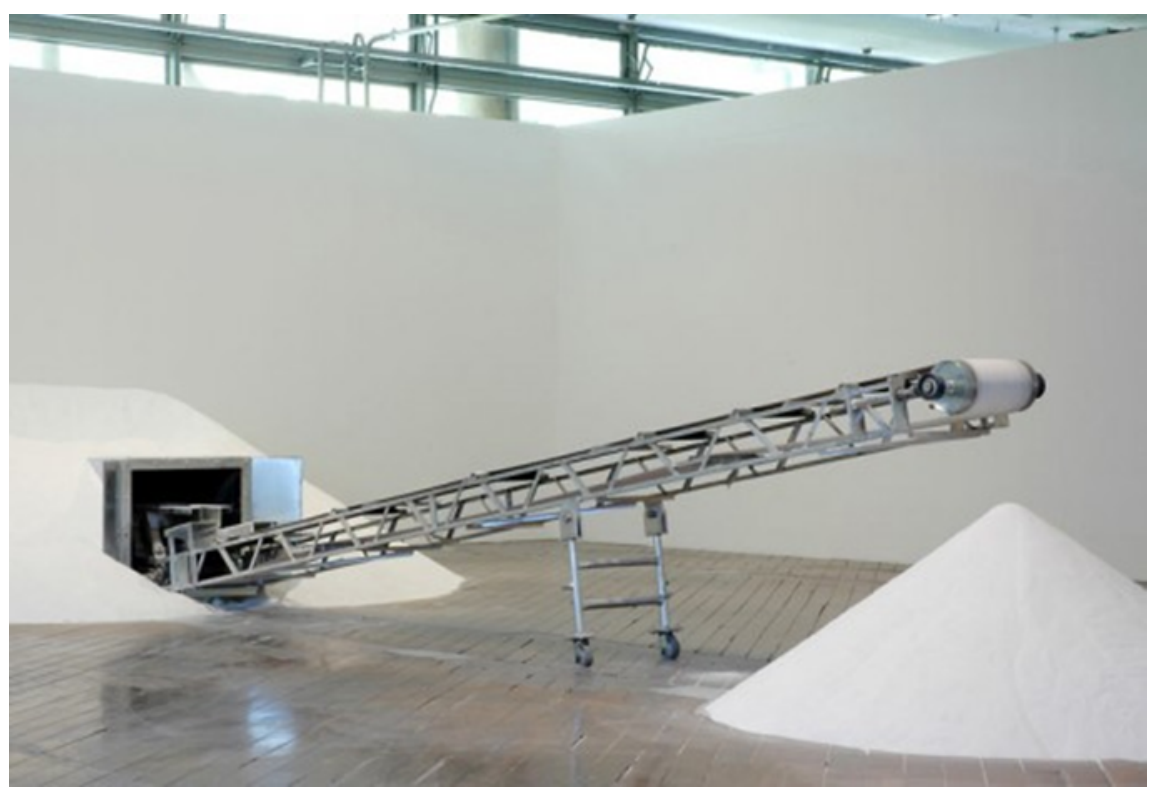

Figura I - Máquina do mundo, 2005. Pó de mármore, correia transportadora, máquina dosadora, o,60 x 0,40 x 5,00 m e 0,70 x 0,70 x 2,00 m. Instituto de Arte de Contemporânea Inhotim. Fotografia de Nelson Kon.

O mármore na história da escultura ocidental representa uma possibilidade de permanência, considerado o material mais nobre para as esculturas. Tanto que era muito utilizado para escultura de personagens imortais, por ser um material imortal. Na Idade Média era visto com ideia de preciosidade, pois nessa época o material tem mais importância que a forma. Vale destacar, ainda, a posição de Michelangelo, que via em um só bloco de mármore a forma perfeita, que exige que o artista a faça, implicando numa espécie de luta fatigante com o material. Mas Laura Vinci não recorre a um bloco de mármore nesta obra, mas ao pó, partícula que foge de nossas mãos com um mero sopro. Este é um paradoxo interessante ressaltado em suas obras, trata-se de um elemento sólido, mas tão minúsculo e leve que pode desaparecer. A pugna passa ser outra.

Máquina do mundo pode ser, ainda, encarado como uma pequena sátira às esculturas clássicas, por utilizar-se da mesma arte - a escultura - mas com uma conotação diferente, em que a matéria fala mais do que a própria forma. Se no período clássico os gregos: 
(...) procuravam representar os seres como que retirados ao universo psicológico, imunes ao sofrimento e à ideia ou presença da morte. Os modelos preferidos dos escultores gregos eram os seres jovens, no esplendor da idade, de corpos perfeitos, imóveis, serenos, harmoniosos, tranquilos, idealizados.$^{\text {[3 }}$

Em Vinci o interesse é outro, o mármore é:

(...) a matéria que simbolicamente está muito associada à eternidade, onde a humanidade deixa sua marca achando que é para sempre. Aqui está no estado [em pó] que seria potencialmente para sempre, num estado que não é para sempre... já foi pó, e pó será pedra $(. .).)^{\sqrt{14}}$

O espectador que visita Máquina mundo estará diante de uma obra silenciosa, apesar de haver uma máquina. O pó de mármore percorre a transportadora vagarosamente até cair do outro lado. A quantidade é tão pequena que não percebemos a alteração nos dois lados.

Ampulheta $!^{15}$ por sua vez, é uma escultura em que há um monte de areia fina sobre uma laje na qual há um furo feito no cimento pelo qual a areia escorre lentamente para o andar inferior. Por ter sido realizada num prédio em ruínas, Ampulheta estava sujeita às variaçóes do meio: vento e umidade. Semelhante à Máquina do mundo, a obra utiliza-se de um elemento sólido e minúsculo, agora areia, e de dois montes, mas com uma particularidade: "Em andares diferentes, cada monte só deixa ver metade da grande ampulheta. Num caso, vê-se a areia escorrer não se sabe bem que destino. No outro, um monte forma-se sem que se conheça direito sua origem" ${ }_{[16}^{16}$ Nesta obra se quiser ver um lado, um monte, o outro se ocultará para o espectador.

${ }^{13}$ SUASSUNA, Ariano. Iniciação à estética. Rio de Janeiro: José Olympio, 20II, p. 295

${ }^{\text {I4 }}$ LAURA VINCI, 2oII. Produzido por Instituto Figueiredo Ferraz. Ribeirão Preto. Disponível em http://www.youtube.com/watch?v=_-26O-9sMxQ. Acesso em 22 de jul. de 2012.

is Essa obra foi importante na carreira artística de Laura Vinci por ser uma obra de passagem, sair de uma poética que utilizava esculturas com ferro e bronze e ir para poética que trabalha com as questóes de fugacidade do tempo, transformaçóes e mudança de estados da matéria.

${ }^{16}$ TASSINARI, op. cit., p. 155 . 
Essas duas obras lidam com elementos sólidos, mas fugazes, diz de uma transformação contínua, imperceptível, mas se apresentam à primeira vista como em repouso. Contudo, aquele que retorna tempos depois nota a diferença no volume dos montes. As esculturas de Vinci recordam que essa transformação é, a todo instante, lenta e rápida, inexorável. Lenta, pois cada partícula que muda de lado não traz consequências imediatas, não se percebe a consequência, e rápida, visto que quando se nota já mudou a sua forma. Esse paradoxo rápido e lento induz a compreender o momento como um quase e um nada. O que essas obras demonstram é justamente a ideia do quase-nada jankélévitchiano, uma sucessão de ocasióes contínuas, um tornar-se, um aparecer e um desaparecer a todo instante. Revelam que a vida não é estática, mas realizada neste tornar-se, a cada ocasião. Todavia se pode argumentar que essas obras em particular não mostram ainda uma ruptura, mas, talvez, só um deslocamento.

\section{Elementos líquidos e orgânicos}

A partir deste ponto há outras duas obras de Vinci: Ainda viva (2007) e Mona Lisa (200I). Essas duas obras ainda tratam da questão da passagem, da transitoriedade. Ainda viva (Figura 2) é uma obra realizada numa sala e se constitui de vidro, mármore, maçãs e marcas de tiro na parede. É a única de suas obras, até então, que lida realmente com um elemento perecível. Nessa obra há um grande bloco de mármore - similar a uma mesa - coberto por maçãs que caem e, num dos cantos, os vidros estão suspensos como um lustre estilizado: parece que se está diante de uma espécie de uma mesa posta para um banquete (ou o que sobrou dele). É interessante observar em Ainda viva a ideia de um antagonismo temporal: o mármore como o permanente e a maçã como o perecível. Coloca frente a frente esses dois tempos, perecível e imperecível, mas não em confronto: ao contrário, os dois convivem harmoniosamente no espaço elaborado por Vinci, apesar do contraste. Para o espectador, a primeira coisa que se destaca é o vermelho da maçã, num espaço tão claro. No entanto, ela está em decomposição (literalmente uma natureza morta). Não se vê o tempo, mas o percebe à medida que a maçã vai escurecendo, lentamente perecendo. O mármore parece desempenhar um papel de coadjuvante na experiência do espectador, pois está lá imóvel, eterno. 
As cores também contribuem para ressaltar a ideia de contraste: o vermelho da maçã (uma cor quente) e o branco do mármore (uma cor fria).

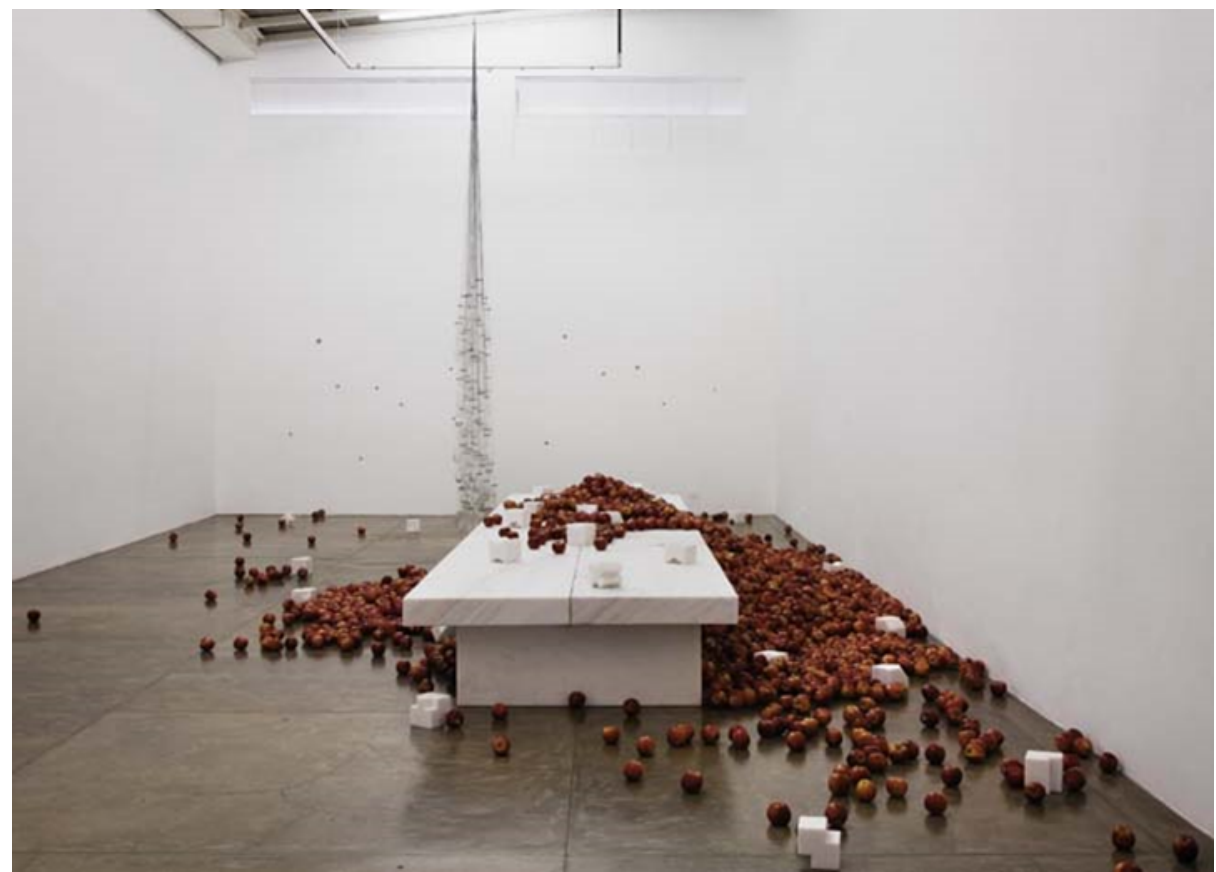

Figura 2 - Ainda viva, 2007. Maça, vidro, mármore. Galeria Nara Roesler, São Paulo. Fotografia de Nelson Kon.

Talvez, Ainda viva, seja uma das obras mais provocativas de Vinci, capaz de nos falar da condição humana. A vida, a realidade, possui essas duas dimensões, próprias à experiência do tempo: o que dura e o que perece. Esse é o ponto de tensão da realidade, tensão esta identificada na história da filosofia, desde Heráclito e Parmênides, e para a qual o pensamento ocidental ainda não obteve resposta satisfatória, um ponto de equilíbrio. Essa tensão entre o efêmero e o permanente está presente na vida do ser humano. É ela que, por um lado, permite reconhecer nossa "medida", os limites próprios e, por outro lado, que algo, deveras, permanece na pessoa. Não se está nos referindo à essência ou substância, mas a um permanecer na sucessão dos modos de ser: cada um de nós nos tornamos a cada instante, somos e não-somos os mesmos. 
O tornar-se é uma série de ocasióes contínuas: estes eventos que aparecem-desaparecem reaparecem a todo momento, sem que haja progresso escalar, sem que se possa aproximar dele como de uma meta previamente estabelecida. No espaço, o objetivo não muda de lugar, enquanto, no tempo, ele se move progressivamente è̀ medida que me arrasta atrás dele. O número infinito de ocasióes reconstitui ao extremo uma continuidade no descontínuo, um fluxo através de fluxos sucessivos 17

"Ser" não é estar imune ao tempo, pois em Aristóteles, mesmo a alma sendo a essência do homem, com sua morte ela deixa de existir. Dentro do conjunto dessa obra de Vinci, o mármore não está isolado da maçã, pois esta deixa vestígios no bloco seja no cheiro ou numa mancha. A marca é outro aspecto ressaltado em Ainda viva, visto que há furos na parede como marcas de tiro. Podem ser vestígios da guerra, da violência urbana, de violência verbal ou de uma simples cirurgia. As marcas são nossas recordaçôes, as pegadas dos eventos, o sinal de que o tempo age.

Ainda viva, que parece retratar a cena de um banquete, pode nos dizer, ainda, que a vida humana seja realmente a cena de um evento, um grande evento. Evento que marca o indivíduo, que indica que o ser humano é um ser perecível, que está em transformação sutil, mas que também tem solidez, consistência.

Um elemento presente na poética de Vinci é a água, em seus vários estados. Mona Lisa (Figura 3) é feita a partir de diversas bacias de vidro com água, ligadas por fios de cobre em que uma resistência elétrica aquece a água até a sua evaporação. A artista busca nesta obra expressar o caráter transformador do elemento, em que a matéria pode estar em vários estados, de algum modo, interligados. $\mathrm{O}$ vidro é concebido pela artista como um líquido solidificado, além do mais, estaria presente na estrutura tanto da água como a do vidro a transitoriedade. O título sugere um diálogo com seu homônimo, uma vez que a obra clássica Monalisa teria presente os três estados da água.

${ }^{17}$ JANKÉLÉVITCH, Vladimir; BERLOWITZ, B. Quelque part dans l'inachevé. Paris: Gallimard, 1978 , p. 89. 


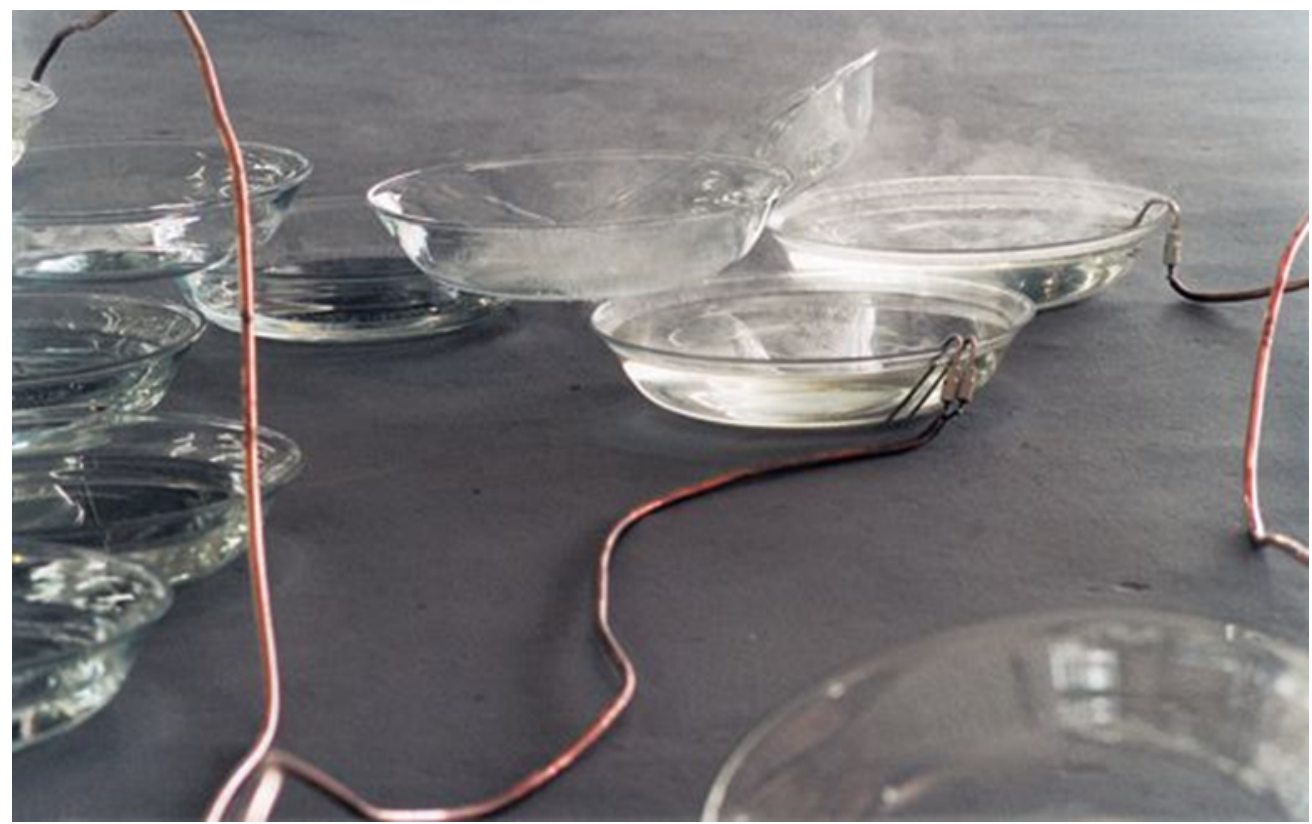

Figura 3 - Mona Lisa, 200I. Vidro, resistência elétrica e água. Centro Cultural São Paulo, São Paulo. Fotografia de Nelson Kon.

Mona Lisa pretende apresentar outro aspecto em relação ao tempo e à mudança no estado da matéria, no modo de ser. No que diz respeito à mudança de estados, tem-se o aspecto positivo que a artista busca ressaltar na passagem, pois não haveria perda, é o mesmo elemento água que evapora e ao chegar ao teto se acumula, retornando em gotículas. Trata-se de uma mudança silenciosa, como se nada acontecesse. Poder-se-ia fazer uma leitura bioquímica da obra que ressalta o ciclo da água, em cujas etapas o elemento continua sendo $\mathrm{H}_{2} \mathrm{O}$, apresentando-se somente em estados diferentes. Mas as obras de Vinci não são tão simplistas, $\mathrm{o}$ tempo em questão não se resume a um mero ciclo.

Esse ciclo é do retorno, mas não do tempo, não se trata do tempo circular. Mesmo sem perdas, já se trata de outra ocasião. É o tempo como na obra de Proust Em busca do tempo perdido, rememorar, procurar as marcas do tempo, mas sem reduzir a rememoração a uma mera volta no tempo. A personagem proustiana volta a suas lembranças, mas ela já possui uma maturidade vivida 
que lhe permite fazer uma leitura diferente dos acontecimentos da Combray de quando era criança. Como reflete Jankélévitch ${ }^{18}$, a primeira vez é sempre única, mesmo a segunda vez já não é a primeira, mas outra ocasião.

A água em Mona Lisa é a mesma quimicamente, até no mesmo estado físico, mas em outro tempo agora. Há o tempo cíclico, mas existe o tempo da ocasião, esse é único. Uma única oportunidade pode mudar tudo num tempo linear. Essa oportunidade é rápida, uma centelha no sentido jankélévitchiano. Assim como em Mona Lisa as bacias de vidro são interligadas umas com as outras, os eventos estão conectados uns aos outros, permeáveis e em fluxo contínuo. É essa transitoriedade do tempo que muda a forma de ser das coisas que comunica a obra:

Mais do que um gosto pela variedade, o que a leva nessa busca é o reconhecimento da passagem e o encadeamento fluido que testemunha o estado de contaminação receptiva e de alteração recíproca na massa do mundo. Essas trocas seriam uma comunicação e um diálogo entre os elementos, se estes se comportassem como linguagem. Mas, em vez disso, eles permanecem, entre todos os estados, num estado de mudez e nudez essenciais, mesmo quando intervêm palavras. ${ }^{19}$

As obras de Laura Vinci exigem do espectador que as experimente e se entregue à sua observação e reflexão. Poder-se-ia dizer que se requisita o exercício da totalidade da alma humana, dentro de uma perspectiva aristotélica: não só a apreciação sensível, mas a participação do prazer de refletir. As obras de Vinci aqui elencadas nos instigam ao processo de sentir a tensão que é o tempo e a pensar na existência que nele se inscreve.

O efêmero na arte contemporânea possui um caráter positivo, não o de um efêmero de superficialidade das coisas e situaçôes, aspecto esse não abolido neste artigo, mas de uma valorização. Uma forma diferente de se relacionar com o

${ }^{18}$ JANKÉLÉVITCH, ı98oa, p. 76.

19 WISNIK, José Miguel. “O branco do rio”. In: VINCI. Laura. Laura Vinci. São Paulo: Editora da Universidade de São Paulo, 2003, p. I6I. 
tempo, de assumi-lo como uma ocasião de oportunidade, como composição de momentos. A poética do efêmero, ainda, nos diz que uma obra de arte não significa necessariamente algo de estático e permanente, mas pode ser movimento e perecível. Ao falar do tempo, que efetiva a imanência, se é provocado necessariamente a pensar também a vida, a condição humana, visto que, como expressa o filósofo francês Jankélévitch, ela é marcada pela tragédia da existência que “(...) é a irreversibilidade do tempo" ${ }^{20}$ Diante da poética examinada, constata-se que a vida é fragilidade, passagem, mas também uma grande oportunidade, realizada a partir de momentos marcantes e únicos.

\section{Referências}

BUCI-GLUCKSMANN, Christine. Esthétique de l'éphémère. Paris: Éditions Galilée, 2003.

CARVALHO, Victa. Dispositivo e experiência: relações entre tempo e movimento na arte contemporânea. In: Revista Poiésis, Niterói, n. I2, p. 39-50, nov. 2008.

JANKÉLÉVITCH, Vladimir. La manière et l'occasion. Paris: Éditions du Seuil, I980.

. Leje-ne-sais-quoi et le presque-rien. Paris: Éditions du Seuil, I980.

JANKÉLÉVITCH, Vladimir; BERLOWITZ, B. Quelque part dans l'inachevé. Paris: Gallimard, 1978.

LAURA VINCI, 2oII. Produzido por Instituto Figueiredo Ferraz. Ribeirão Preto. Disponível em http://www.youtube.com/watch?v=_-26O-9sMxQ. Acesso em 23 nov. 202I.

LISCIANI-PETRINI, Enrica. In Dialogo con Vladimir Jankélévitch. Milão; Paris: Vrin, 2009.

NAVES, Rodrigo. "Mona Lisa no meio do redemoinho". In: O vento e o moinbo: ensaios sobre arte contemporânea. São Paulo: Companhia das Letras, 2007.

${ }^{20}$ JANKÉLÉVITCH; BERLOWITZ, op. cit., p. 258. 
NIETZSCHE, Friedrich Wilhelm. Obras incompletas. Coleção Os pensadores, v. 2. São Paulo: Nova Cultural, 1987.

SUASSUNA, Ariano. Iniciação à estética. Rio de Janeiro: José Olympio, 2oII. TASSINARI, Alberto. "Formas do repouso". In: VINCI. Laura. Laura Vinci. São Paulo: Editora da Universidade de São Paulo: Imprensa Oficial do Estado, 2003.

VINCI, Laura. Entrevista de Laura Vinci a Hélio Hara. Seção textos. Disponível em http://https://www.lauravinci.com.br/textos. Acesso em 23 nov. 202I.

WISNIK, José Miguel. “O branco do rio”. In: VINCI. Laura. Laura Vinci. São Paulo: Editora da Universidade de São Paulo: Imprensa Oficial do Estado, 2003.

Resumo: Hoje já não se pode afirmar que um objeto de arte seja estático e permanente. $\mathrm{O}$ fugidio, o movimento e o tempo são assimilados pela arte e objeto passa ser efêmero também. A artista plástica Laura Vinci, em alguns de seus trabalhos, tem esses elementos como marcas características. Por outro lado, essa nova concepção artística da temporalidade encontra nítida ressonância na filosofia de Vladimir Jankélévitch. Destarte, esse artigo propóe-se a fazer um diálogo entre a poética de Vinci e o pensamento de Jankélévitch, que por meio de seu conceito de quasenada (presque-rien) possui estreito vínculo com tema da efemeridade.

Palavras-chave: Efêmero; Quase-nada; Laura Vinci; Jankélévitch.
AbSTRACT: Today it can no longer be said that an object of art is static and permanent. The elusive, the movement and the time are assimilated by art and the object becomes ephemeral too. The plastic artist Laura Vinci, in some of her works, has these elements as characteristic marks. In addition, this new artistic conception of temporality finds clear resonance in Vladimir Jankélévitch's philosophy. Therefore, this article proposes a dialogue between Vinci's poetics and Jankélévitch's thought, which through its concept of almost-nothing (presque-rien) has a close link to the theme of ephemerality.

Keywords: Ephemeral; Almostnothing; Laura Vinci; Jankélévitch. 